\title{
PENYULUHAN PEMAKAIAN PERALATAN LISTRIK DI PERUMAHAN KODYA ASRI MATARAM
}

\section{Counseling ehe Use of Electric Equipment at Kodya Asri Mataram}

\section{Ida Bagus Fery Citarsa*, I Nyoman Wahyu Satiawan, Supriono, I Ketut Wiryajati, Ni Made Seniari}

Program Studi Teknik Elektro Universitas Mataram

Jalan Majapahit No. 62 Mataram Nusa Tenggara Barat

${ }^{*}$ Alamat korespondensi : ferycitarsa@unram.ac.id

(Tanggal Submission: 22 Juni 2020, Tanggal Accepted: 31 Agustus 2020)

\begin{abstract}
ABSTRAK
Penggunaan peralatan listrik rumah tangga bagi masyarakat secara umum memiliki beberapa permasalahan yaitu sebagian masyarakat belum memahami penggunaan peralatan listrik rumah tangga secara aman dan hemat. Permasalahan di atas juga dialami oleh warga masyarakat yang berada di Lingkungan RT. III Perumahan Kodya Asri Mataram. Untuk mengatasi masalah yang dihadapi oleh masyarakat di ingkungan tersebut, maka solusi yang ditawarkan adalah dengan dilakukannya penyuluhan. Pada jadwal yang telah ditentukan tim pelaksana yang beranggotakan staf pengajar Jurusan Teknik Elektro Fakultas Teknik Universitas Mataram telah melaksanakan kegiatan pengabdian kepada masyarakat di Lingkungan RT III Perumahan Kodya Asri Mataram berupa penyuluhan mengenai mengenai teknik pemakaian peralatan listrik rumah tangga secara aman dan hemat. Berdasarkan hasil wawancara beberapa waktu setelah penyuluhan diketahui bahwa kegiatan penyuluhan ini telah memberikan pengetahuan kepada masyarakat di Lingkungan RT III Perumahan Kodya Asri Mataram mengenai teknik pemakaian peralatan listrik rumah tangga secara aman dan hemat. Hal ini akan dapat menunjang keselamatan masyarakat di lingkungan tersebut dalam menggunakan peralatan listrik serta dapat menghemat pengeluaran rumah tangga terkait dengan penggunaan tenaga listrik secara keberlanjutan.
\end{abstract}

Kata kunci : peralatan listrik, rumah tangga, hemat, aman

\section{PENDAHULUAN}

Listrik merupakan salah satu kebutuhan pokok di era modern ini. Tuntutan akan kualitas hidup yang lebih baik telah menyebabkan diproduksinya berbagai peralatan listrik untuk memenuhi kebutuhan hidup manusia. Energi listrik mempunyai beberapa kelebihan dibanding energy yang lain diantaranya adalah (Suryatmo, 1992) :

1. Lebih mudah disalurkan.
2. Lebih mudah didistribusikan ke daerah yang lebih luas.

3. Lebih mudah diubah ke dalam bentuk energy lain, misalnya menjadi energy panas, cahaya, atau mekanik.

Listrik sudah menjadi kebutuhan bagi semua lapisan masyarakat. Kegunaan dan manfaat keberadaan listrik telah dirasakan oleh semua kalangan. Dunia bisnis, perkantoran, instansi, warga masyarakat, dan lain sebagainya tidak lepas 
dari penggunaan listrik dalam menjalankan segala aktivitasnya sehari-hari. Hampir semua peralatan dan perlengkapan yang dipergunakan dapat dijalankan dengan memanfaatkan energi listrik. Barang-barang seperti, air conditioner (AC), lemari es, telepon genggam, penanak nasi, sampai alat transportasi kereta api dan lain sebagainya membutuhkan energi listrik. Dengan demikian, kebutuhan energi listrik sangat penting dan harus selalu terpenuhi dalam kehidupan. Untuk mencukupi kebutuhan energi listrik tersebut, tentunya diperlukan sumber- sumber energi yang harus selalu tersedia.

PLN memiliki beberapa jenis pembangkit tenaga listrik dalam rangka memenuhi kebutuhan tenaga listrik masyarakat. Pembangkit tenaga listrik berfungsi untuk mengkonversikan sumber daya energy primer menjadi energy listrik. Pembangkit tenaga listrik konvensional mencakup (Zuhal, 2000) :

1. Pembangkit Listrik Tenaga Uap (PLTU)

2. Pembangkit Listrik Tenaga Air (PLTA)

3. Pembangkit Listrik Tenaga Gas (PLTG)

4. Pembangkit Listrik Tenaga Diesel (PLTD)

5. Pembangkit Listrik Tenaga Panas Bumi (PLTP)

6. Pembangkit Listrik Tenaga Nuklir (PLTN)

Sumber- sumber energi listrik dapat diperoleh dari berbagai bahan dan tempat. Tetapi, pemanfaatan sumber- sumber energi listrik ini harus dilakukan secara efektif dan efisien. Selain itu, penggunaan energi listrik hendaknya dapat dilakukan secara hemat untuk menjaga kesinambungan energi sekarang, hari ini, esok, dan masa yang akan datang. Penghematan energi listrik dipandang perlu demi stabilitas dan kelangsungan sumber- sumber listrik itu sendiri (Rifai, 2014) .

Kodya Mataram sebagai ibukota Propinsi Nusa Tenggara Barat mengalami pembangunan yang cukup pesat pada beberapa tahun terakhir ini. Hal ini ditandai dengan semakin banyaknya perumahan-perumahan yang dibangun untuk memenuhi kebutuhan papan bagi penduduk Kodya Mataram yang semakin bertambah dengan pesat dan peningkatan taraf ekonomi penduduk. Salah satu perumahan yang berada di Kodya Mataram adalah Perumahan Bumi Kodya Asri Jempong Mataram atau yang biasa disingkat menjadi Perumahan Kodya Asri Mataram. Salah satu lingkungan yang terdapat di dalam perumahan ini adalah lingkungan RT. III yang melingkupi warga yang mendiami rumah-rumah di sekitar Jalan Sunan Malik Ibrahim dan sekitarnya.

Penggunaan peralatan listrik rumah tangga bagi masyarakat secara umum memiliki beberapa permasalahan yaitu sebagian masyarakat belum memahami penggunaan peralatan listrik rumah tangga secara aman. Pengguna energi listrik terbesar adalah bersumber dari kegiatan ibu rumah tangga seperti mencuci pakaian dengan mesin cuci, setrika, televisi dan sebagainya. Masih banyak pengguna yang kurang memperhatikan bahaya yang timbul akibat instalasi listrik yang kurang baik. Khususnya di rumah tangga yang mayoritas berada didalam rumah dan sebagai pengguna listrik utama adalah ibu rumah tangga yang memiliki keterbatasan pengetahuan dan kemampuan mengenai kelistrikan (Anggraini, 2019).

Masyarakat juga belum memahami penggunaan peralatan listrik rumah tangga secara hemat untuk menunjang efisiensi dan konservasi ketenagalistrikan rumah tangga secara keberlanjutan. Permasalahan-permasalahan tersebut menyebabkan penggunaan peralatan listrik rumah tangga dapat menjadi tidak aman dan hemat.

Permasalahan di atas juga dialami oleh warga masyarakat yang berada di Lingkungan RT. III Perumahan Kodya Asri Mataram. Hal ini disebabkan oleh latar belakang pendidikan warga yang bukan merupakan pendidikan ketenagalistrikan dan kurangnya sosialisasi. Untuk mengatasi masalah yang dihadapi oleh masyarakat di Lingkungan RT III Perumahan Kodya Asri 
Mataram yang berkenaan dengan penggunaan peralatan listrik rumah tangga secara aman dan hemat, maka solusi yang ditawarkan adalah dengan dilakukannya penyuluhan tentang penggunaan peralatan listrik rumah tangga secara aman dan hemat kepada masyarakat di Lingkungan RT III Perumahan Kodya Asri Mataram. Penyuluhan ini akan membuat masyarakat dapat memahami cara penggunaan peralatan listrik rumah tangga secara aman untuk menunjang keselamatan ketenagalistrikan rumah tangga secara keberlanjutan. Penyuluhan ini juga akan membuat masyarakat dapat menggunakan peralatan listrik rumah tangga secara hemat untuk menunjang efisiensi dan konservasi ketenagalistrikan rumah tangga secara keberlanjutan.

\section{METODE KEGIATAN}

Kegiatan pengabdian kepada masyarakat ini dilaksanakan melalui 3 tahapan, yaitu tahap persiapan, tahap pelaksanaan, dan tahap evaluasi.

\section{Tahap persiapan}

1. Kunjungan ke masyarakat yang akan diberi penyuluhan yaitu masyarakat di Lingkungan RT III Perumahan Kodya Asri Mataram.

2. Pengenalan karakter masyarakat yang akan diberi penyuluhan.

3. Penetapan jadwal kegiatan penyuluhan bersama masyarakat tersebut.

4. Pengumpulan materi penyuluhan

5. Pembagian materi penyuluhan pada setiap anggota pelaksana PPM

\section{Tahap pelaksanaan}

1. Penyuluhan kepada masyarakat oleh setiap anggota pelaksana.

2. Tanya jawab antara masyarakat dengan penyuluh.

\section{Tahap evaluasi}

1. Kunjungan ke masyarakat untuk mengetahui hasil penyuluhan terkait dengan perilaku penggunaan peralatan listrik rumah tangga secara aman dan hemat

2. Membuat laporan hasil pelaksanaan PPM.

\section{HASIL DAN PEMBAHASAN}

\section{Tahap Persiapan}

Sesuai dengan pendekatan/metode pelaksanaan kegiatan yang telah direncanakan maka kegiatan pengabdian pada masyarakat ini diawali dengan melakukan kunjungan ke masyarakat yang akan diberi penyuluhan yaitu dengan mengunjungi kediaman Ketua RT III Perumahan Kodya Asri Mataram. Di pertemuan tersebut, tim pelaksana menyampaikan rencana kegiatan pengabdian pada masyarakat kepada Ketua RT agar mendapatkan persetujuan terlebih dahulu. Selanjutnya dilakukan wawancara kepada Ketua RT terkait karakter masyarakat di lingkungan tersebut terutama terkait dengan kondisi social, ekonomi dan pendidikan masyarakat di sana. Diperoleh keterangan bahwa kondisi social, ekonomi dan pendidikan masyarakat di sana ratarata menengah sehingga memudahkan untuk memberi materi penyuluhan dengan bahasa yang lebih teknis. Selain itu dilakukan pula pembahasan mengenai penetapan jadwal kegiatan penyuluhan bersama masyarakat tersebut. Persiapan selanjutnya adalah mengumpulkan materi yang akan diberikan pada saat penyuluhan. Materi sebagian besar diambil dari internet dan sebagian kecil dari buku literature terkait topic yang akan diberikan yaitu listrik aman dan hemat. Setelah materi terkumpul, anggota tim berkumpul dan mendiskusikan pembagian materi penyuluhan yang akan disampaikan masing-masing anggota pada saat penyuluhan.

\section{Tahap pelaksanaan}

Pada hari yang telah disepakati antara tim pelaksana dengan Ketua RT mewakili warga masyarakat di lingkungan RT III, kegiatan penyuluhan ini dilaksanakan di kediaman Ketua RT. Setelah ibu-ibu RT tersebut sebagian besar hadir, 
akhirnya acara dimulai. Diawali dengan sambutan dari Ketua RT terkait dengan kehadiran tim pelaksana kegiatan pengabdian pada masyarakat dari Jurusan Teknik elektro Fakultas Teknik Universitas Mataram dan kegiatan penyuluhan yang akan dilaksanakan.

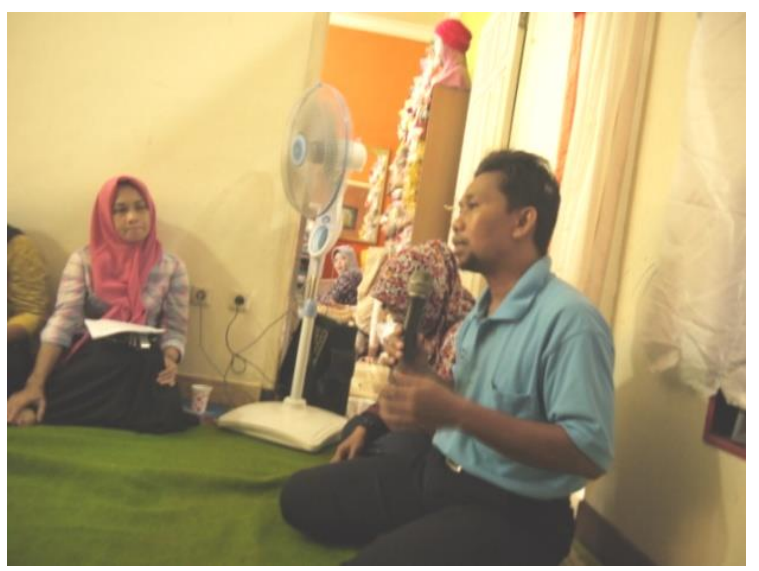

Gambar 1. Sambutan dari Ketua RT III Perumahan Kodya Asri Mataram

Acara selanjutnya adalah sambutan dari ketua tim pelaksana kegiatan pengabdian pada masyarakat dari Jurusan Teknik elektro Fakultas Teknik Universitas Mataram terkait dengan ucapan terima kasih atas kesediaan warga di RT tersebut untuk menerima kehadiran tim dan memperkenalkan personalia tim berikut materi yang akan disampaikan.

Penyuluhan dimulai oleh pemateri pertama yaitu Ida Bagus Fery Citarsa, ST., MT yang menyampaikan materi tentang "Potensi Bahaya Listrik Rumah Tangga" yang di dalamnya membahas tentang fungsi peralatan pada instalasi listrik, prinsip kerja instalasi listrik, cara yang aman dalam memanfaatkan aliran listrik, hal-hal yang perlu dilakukan jika menghadapi bahaya listrik, dan keamanan dan keselamatan penggunaan listrik (Novianta, 2018).

Penyuluhan selanjutnya dilaksanakan oleh pemateri kedua yaitu I Nyoman Wahyu Satiawan, ST., M.Sc., Ph.D yang menyampaikan materi tentang "Keselamatan Penggunaan Listrik" yang di dalamnya membahas langkah-langkah pengamanan instalasi penyediaan tenaga listrik dan pengamanan pemanfaat tenaga listrik untuk mewujudkan kondisi andal dan aman bagi instalasi dan kondisi aman dari bahaya bagi manusia dan makhluk hidup lainnya, serta kondisi ramah lingkungan, di sekitar instalasi tenaga listrik (Darmana, 2018).

Penyuluhan selanjutnya dilaksanakan oleh pemateri ketiga yaitu Supriono, ST., MT. yang menyampaikan materi tentang "Pemakaian Energi Listrik Rumah Tangga" yang di dalamnya membahas tentang pengenalan energi listrik, pengenalan SNI pencahayaan lampu dan cara menghitung energi listrik di rumah tangga (Fahriannur, 2017)

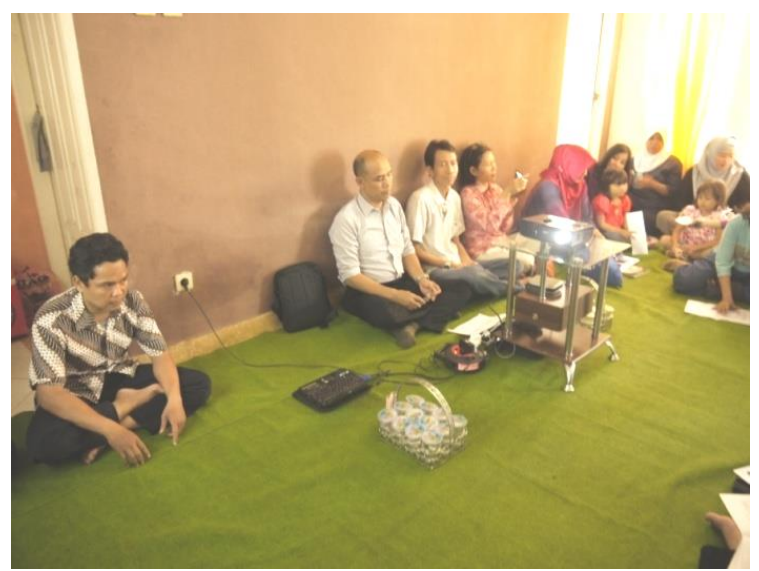

Gambar 2. Pemateri sedang menyampaikan materi

Penyuluhan selanjutnya dilaksanakan oleh pemateri keempat yaitu I Ketut Wiryajati, ST., MT. yang menyampaikan materi tentang "Lampu Hemat Listrik" yang di dalamnya membahas tentang Lampu Hemat Listrik (LHL), Ballast Elektronik (BE), dan penghematan diperoleh dengan menggunakan Lampu Hemat Listrik di rumah tangga (Pujotomo, 2015).

Penyuluhan terakhir dilaksanakan oleh pemateri terakhir yaitu Ni Made Seniari, ST., MT. yang menyampaikan materi tentang "Pemakaian peralatan listrik rumah tangga secara hemat" yang di dalamnya membahas tentang beberapa cara yang dapat dilakukan untuk menghemat energi listrik di lingkungan rumah dengan menyiasati pemakaian barang-barang atau peralatan- 
peralatan yang menggunakan energi listrik (Rifai, 2014)

Setelah semua anggota tim pelaksana kegiatan pengabdian pada masyarakat menyampaikan materinya masing-masing, maka acara selanjutnya adalah sesi tanya jawab antara peserta penyuluhan dengan tim pelaksana terkait dengan isi materi penyuluhan yang baru saja disampaikan. Terdapat beberapa informasi yang diberikan merupakan hal baru bagi masyarakat peserta penyuluhan di lingkungan tersebut yang kebanyakan adalah ibu-ibu rumah tangga sehingga terjadi tanya jawab yang menyebabkan sesi ini berlangsung secara menarik.

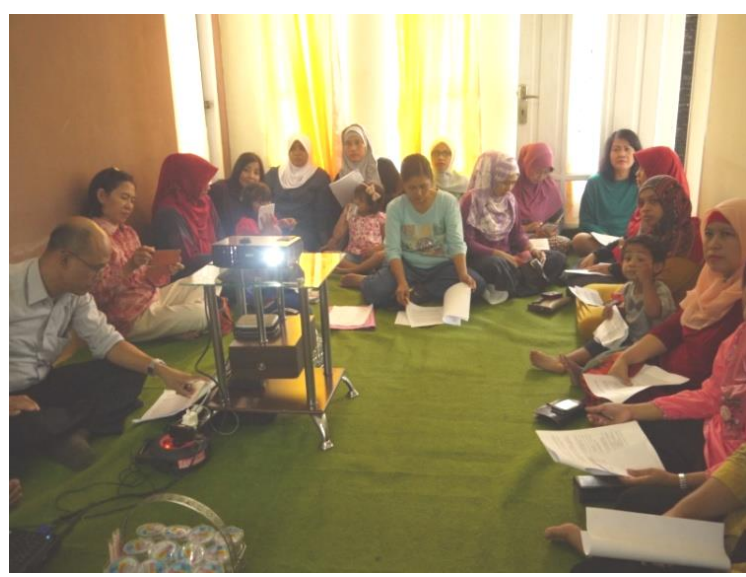

Gambar 3. Sesi tanya jawab antara peserta penyuluhan dengan tim pelaksana

Setelah sesi tanya jawab berakhir, akhirnya berakhir pula kegiatan penyuluhan. Sebagai penutup acara, disampaikanlah ucapan terima kasih dari ketua tim pelaksana kepada Ketua RT dan ibu-ibu di lingkungan RT III Perumahan Kodya Asri Mataram.

\section{Tahap evaluasi}

Untuk tahap terakhir yaitu kunjungan kembali ke masyarakat di lingkungan RT III Perumahan Kodya Asri Mataram untuk mengetahui hasil penyuluhan terkait dengan perilaku penggunaan peralatan listrik rumah tangga secara aman dan hemat di lingkungan tersebut. Berdasarkan hasil wawancara terhadap beberapa warga masyarakat diperoleh hasil bahwa mereka telah menerapkan petunjuk-petunjuk yang telah diberikan tim pelaksana pada saat penyuluhan dalam menggunakan peralatan listrik rumah tangga secara aman dan hemat di rumah tangga mereka. Berdasarkan hasil wawancara tersebut maka dapat dinyatakan bahwa kegiatan penyuluhan ini telah memberikan pengetahuan kepada masyarakat di Lingkungan RT III Perumahan Kodya Asri Mataram mengenai teknik pemakaian peralatan listrik rumah tangga secara aman dan hemat untuk menunjang keselamatan masyarakat di lingkungan tersebut dalam menggunakan peralatan listrik serta dapat menghemat pengeluaran rumah tangga terkait dengan penggunaan tenaga listrik secara keberlanjutan.

\section{KESIMPULAN DAN SARAN}

Kesimpulan yang dapat diambil dari kegiatan pengabdian kepada masyarakat kali ini adalah tim pelaksana yang beranggotakan staf pengajar Jurusan Teknik Elektro Fakultas Teknik Universitas Mataram telah melaksanakan kegiatan pengabdian kepada masyarakat di Lingkungan RT III Perumahan Kodya Asri Mataram berupa penyuluhan mengenai mengenai teknik pemakaian peralatan listrik rumah tangga secara aman dan hemat. Berdasarkan hasil wawancara dapat diketahui bahwa kegiatan penyuluhan ini telah memberikan pengetahuan kepada masyarakat di Lingkungan RT III Perumahan Kodya Asri Mataram mengenai teknik pemakaian peralatan listrik rumah tangga secara aman dan hemat untuk menunjang keselamatan masyarakat di lingkungan tersebut dalam menggunakan peralatan listrik, serta dapat menghemat pengeluaran rumah tangga terkait dengan penggunaan tenaga listrik secara keberlanjutan.

Saran yang dapat diberikan dalam kegiatan pengabdian kepada masyarakat selanjutnya kegiatan penyuluhan ini dapat dilakukan di lebih banyak lokasi lagi sehingga lebih banyak masyarakat yang akan dapat mengerti mengenai teknik pemakaian peralatan listrik rumah tangga secara aman dan hemat. 


\section{UCAPAN TERIMA KASIH}

Tim penulis menyampaikan terima kasih kepada LPPM Unram dan warga Lingkungan RT III Perumahan Kodya Asri Mataram.

\section{DAFTAR PUSTAKA}

Anggraini, Y., Yuniahastuti, I.T., 2019. Efisiensi Pemakaian Listrik Dengan Pelatihan Saving Energy Di Desa Panemon, Jurnal Abdi, 5(1) : 7-14.

Darmana, T., Erlina, Hidayat S., Diantari, R.A., Ratnasari, T., Jumiati, Soewono, S., 2018. Sosialisasi Bahaya Dan Keselamatan Penggunaan Listrik Di Kelurahan Duri Kosambi, Cengkareng. Terang, 1(1): 96-105, https://Doi.Org/10.33322/Terang.V1i1. 138.

Fahriannur, A., Hananto, Y., 2017. Penyuluhan Penghematan Energi Listrik Di TK Mambaul Ulum Kecamatan Sukowono
Kabupaten Jember. Prosiding Seminar Nasional Hasil Pengabdian kepada Masyarakat 2017 ISBN : 978-60214917-4-4.

Novianta, M.A. 2018. Penyuluhan Potensi Bahaya Listrik Rumah Tangga Untuk Ibu-lbu LPMD Dusun Totogan, Madurejo, Prambanan, Sleman, Diy. Jurnal Dharma Bakti-LPPM IST Akprind Yogyakarta, 1(2) : $186-195$.

Pujotomo, I., 2015. Hemat Listrik Dengan Lampu Hemat Listrik. Jurnal Energi \& Kelistrikan, 7(2): 103 - 107.

Rifai, A., 2014. Buku Pintar Mengatasi Listrik di Rumah. CV. Gema Buku Nusantara: Bandung

Suryatmo, F., 1992. Dasar-Dasar Teknik Listrik, Penerbit PT. Rineka Cipta, Jakarta.

Zuhal, 2000. Dasar Teknik Tenaga Listrik dan Elektronika Daya, Penerbit PT. Gramedia Pustaka Utama, Jakarta. 